\title{
PATTERNS IN INVERTEBRATE DRIFT FROM AN ALPINE KARST AQUIFER OVER A ONE YEAR PERIOD
}

\author{
DINAMIKA PLAVLJENJA VODNIH NEVRETENČARJEV \\ IZ ALPSKEGA KRAŠKEGA VODONOSNIKA V OBDOBJU \\ ENEGA LETA
}

\author{
Maja OPALIČKI SLABE ${ }^{1}$
}

\begin{abstract}
UDC 551.444:595.34(234.323.6)

Maja Opalički Slabe: Patterns in invertebrate drift from an Alpine karst aquifer over a one year period

Patterns in invertebrate drift in the alpine karst Lipnik spring (Julian Alps, Slovenia) were investigated over a one year period. Monthly samplings of one permanent and two temporary springs, and one sampling of a spring brook benthos, yielded 23 Copepoda and Ostracoda species. More species (12) were found in the permanent than in the temporary springs (8 and 7), Elaphoidella phreatica (Sars, 1862) being the most frequent in all of them. No correlation was observed between precipitation and drift densities or the numbers of species in the permanent spring. In the temporary springs there were correlations between precipitation and the Shannon diversity index, equitability and changes in community composition. Conductivity of the water was the only physical parameter in the springs that correlated with precipitation. Species accumulation curves reached the asymptotes in all the springs but not for benthos.

Keywords: alpine karst aquifer, Lipnik spring, groundwater, drift, Copepoda, Ostracoda.
\end{abstract}

Izvleček

UDK 551.444:595.34(234.323.6)

Maja Opalički Slabe: Dinamika plavljenja vodnih nevretenčarjev iz alpskega kraškega vodonosnika $v$ obdobju enega leta

V alpskem kraškem izviru Lipnik (Julijske Alpe, Slovenija) smo preiskovali dinamiko plavja vodnih nevretenčarjev v obdobju enega leta. $\mathrm{V}$ mesečnih vzorčenjih enega stalnega in dveh občasnih izvirov ter enkratnim vzorčenjem bentosa potoka Lipnik smo zbrali 23 vrst ceponožcev in dvoklopnikov. Rezultati raziskave so razkrili, da je bilo več vrst zbranih iz stalnega (12) kot iz občasnih izvirov (8 in 7). V vseh je številčno prevladovala vrsta Elaphoidella phreatica (Sars, 1862). V nobenem izviru ni bilo povezave med padavinami in gostoto plavja ter številom vrst. Povezava pa se je pojavila v občasnih izvirih med padavinami in Shannonovim indeksom in ravnovesjem ter spremembo v sestavi združbe. Edina fizikalna lastnost vode v izvirih, ki je bila v povezavi s padavinami, je bila prevodnost. Krivulje vrstne akumulacije so dosegle asimptoto pri vseh izvirih, v bentosu potoka pa ne.

Ključne besede: alpski kraški vodonosnik, izvir Lipnik, podzemna voda, plavje, ceponožci, dvoklopniki.

\section{INTRODUCTION}

Karst aquifers are important reservoirs of vast amounts of potable freshwater. They are also complex but truncated underground ecosystems with diverse faunal and microbial communities (Gibert 2001). Karst aquifers are found in soluble and fractured carbonate rocks (limestone, dolomite) (Worthington \& Smart 2004) and are divided into three subsystems. The epikarst zone is a layer at the top of the karstic bedrock, which slowly graduates into the vadose (unsaturated) and deep phreatic (saturated) zones. Water flows more or less vertically through the aquifer to the water table and then horizontally until it reaches the surface as a karst spring (Smart \& Worthington 2004).

\footnotetext{
${ }^{1}$ National Institute of Biology, Večna pot 111, SI-1000 Ljubljana, Slovenia, e-mail: maja.opalicki.slabe@nib.si, University of Nova Gorica, Graduate School, Vipavska 13, SI-5000 Nova Gorica, Slovenia.
}

Received/Prejeto: 12.12.2014 
Alpine karst occurs at high altitudes in many mountain areas, and is characterized by colder conditions, less abundant vegetation, seasonal snow and snow melt, and the presence of glaciers (Smart 2004). The alpine karst in Slovenia covers $20 \%$ of all karstic area, mainly in the north and northwest part of the country - the Julian Alps, the Karavanke, the Kamnik-Savinja Alps, and most of the high subalpine plateaus (Knez \& Kranjc 2009).

Groundwater fauna is well adapted to the subsurface environment and exhibits several morphological, physiological and ethological characteristics (Culver \& Pipan 2013). Stygobionts are obligatory hypogean and spend their complete life in groundwater (Gibert 2001). Recent data from Slovenia show that there are 210 known stygobiont species and subspecies, 120 of them endemic, which makes Slovenia one of the richest areas with stygobionts in the world (Sket et al. 1991; Sket 1999a, b; Malard et al. 2009). Various methods are used for sampling groundwater fauna in the karst aquifers, depending on the accessibility of their habitats (Pospisil 1992). Karst springs can be used as access points for collecting groundwater fauna as drift and benthos in the spring mouths (Gibert 1986; Mori \& Brancelj 2013). Furthermore, water from monitoring wells and boreholes can be pumped up and filtered (Malard et al. 1996; Hahn \& Fuchs 2009). In caves, percolating water from the cave ceiling (Pipan 2003; Pipan \& Brancelj 2004; Pipan 2005;
Moldovan et al. 2007; Papi \& Pipan 2011; Culver et al. 2012) and water from puddles, pools and cave streams (Brancelj 2002; Camacho et al. 2006; Fišer \& Zagmajster 2009; Culver et al. 2012) can be sampled. Research on groundwater fauna distribution is important for the better understanding of biodiversity patterns and ecosystem processes, and has potential applications as bioindicators for hydrological connectivity (Pipan \& Culver 2007) and quality of the groundwater (Malard et al. 1996; Boulton et al. 2008; Stein et al. 2010).

This study is a continuation of the previous investigations of Lipnik springs by Mori and Brancelj (2013) and others in which environmental impacts on the spring communities of macroinvertebrates and lower crustacean in the Triglav national park were investigated (Mori \& Brancelj 2006), and the drift from springs in the Julian Alps, the Karavanke and the Kamnik-Savinja Alps compared (Mori et al. 2011b).

The main objective of this study was to investigate patterns in groundwater drift from the Alpine aquifer at the interface of the vadose and phreatic zones and to determine whether those patterns can be related to the amount of precipitation in the studied area. Alongside, species accumulation curves were calculated to estimate the sampling effort needed for accurate estimation of species richness.

\section{MATERIALS AND METHODS}

\section{STUDY SITE}

The Lipnik spring system $\left(46^{\circ} 23^{\prime} 04^{\prime \prime} \mathrm{N}, 14^{\circ} 01^{\prime} 37^{\prime \prime} \mathrm{E}\right)$ is situated in the Radovna valley near Bled in the eastern part of the Julian Alps (Fig. 1). The water appears in a series of one permanent and several temporary springs under the steep slopes of the north-eastern part of the Pokljuka plateau, at an altitude of between 665 and $692 \mathrm{~m}$ a.s.l. The spring system consists of several spring outlets from the same geological fracture in a diagonal distance of $60 \mathrm{~m}$. Outlet Lipnik 1 (L1) is the permanent spring located $60 \mathrm{~m}$ downstream from the other springs (Fig. 1, bottom right). The most upstream outlets, Lipnik 2 (L2) and Lipnik 3 (L3), are temporary or "linear" springs that, during low flow water, recharge 10 metres downstream from the uppermost site (Fig. 1, bottom right). The karst aquifer of Pokljuka is positioned in the massif of limestone and thick-grained dolomite of the Triassic age (Buser 1987). Annual mean precipitation over the area in the period 2004-2013 was $1956 \mathrm{~mm}$ and the annual mean air temperature for the same time period was $8.6^{\circ} \mathrm{C}$ (Bohinjska Češnjica meteorological station) (Slovenian Environment Agency 2014).

\section{SAMPLING METHODS}

Two types of sampling campaigns were carried out. The first was monthly drift sampling of one permanent (L1) and two temporary (L2, L3) outlets of the Lipnik spring over a one year period from December 2010 to January 2012. The second was a one-off collection of benthic samples along the Lipnik brook with a Hess sampler (in April 2012). The brook was divided into three sections (Spring brook 1-SB1 at the spring mouth, Spring brook 2 - SB2 $100 \mathrm{~m}$ from the spring mouth and Spring brook 3 - SB3 $150 \mathrm{~m}$ from the spring mouth, near the confluence with the Radovna river) (Fig. 1, bottom right). Four spatial replicates were taken at each section.

Drift was sampled with drift nets (net mouth diameter $0.2 \mathrm{~m}$, length of filtering cone $1 \mathrm{~m}$, mesh size $100 \mu \mathrm{m})$ that were placed for 24 hours in the mouths of the springs (L1, L2, L3). At the end of drift net was 


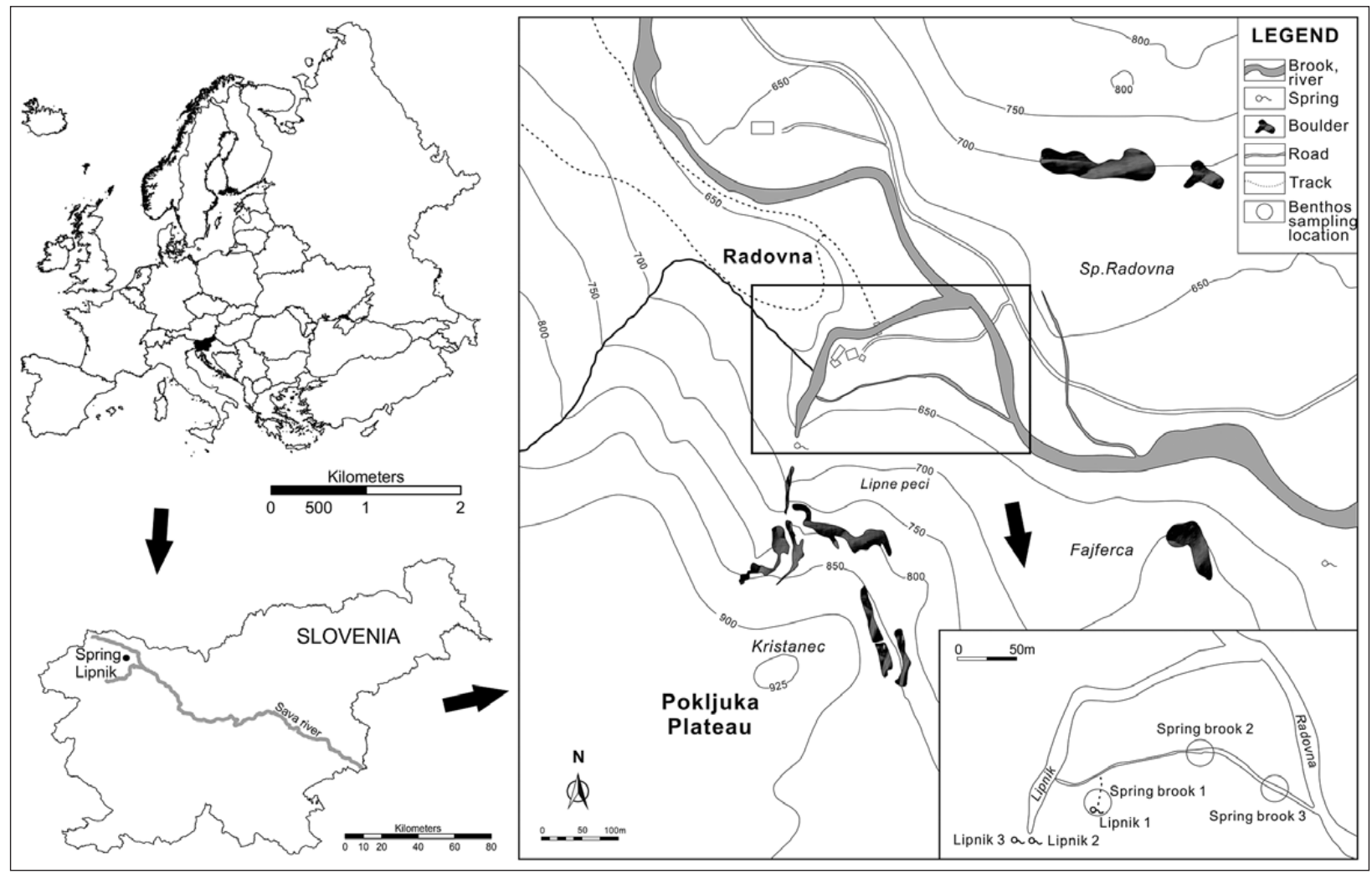

Fig.1: Location of the Lipnik spring. The sampling sites are enlarged at the bottom right side.

attached a special filtering bottle (Brancelj 2004), to prevent clogging of the filtering cone due to abundant material washed from the spring.

Before sampling the fauna several ecological parameters were measured in each spring: the water depth (ruler); flow velocity (OTT Acoustic Digital Current meter); $\mathrm{pH}$, temperature and conductivity (WTW Multiline P4, TetraCon 325) and oxygen content (WTW Multiline P4, CellOx 325).

The brook benthos was sampled with a Hess sampler, a cylindrical tube (diameter $0.3 \mathrm{~m}$, surface $0.07 \mathrm{~m}^{2}$ ) with a screened inflow on one side and a filtering net (length $0.7 \mathrm{~m}$, mesh size $100 \mu \mathrm{m}$ ) attached to the other side. The sampler was placed at the bottom of the brook and, while water was passing through, larger stones were gently rubbed and the gravel and sand stirred by hand. After three minutes, the net was removed and samples collected in the filtering bottle (Brancelj 2004) attached to the end of the net. Samples were preserved in $70 \%$ ethanol until being analysed.

\section{LABORATORY ANALYSIS}

Specimens of different taxa were sorted and counted using a stereo microscope (Olympus SZX 9). Meiofauna (Ostracoda, Cyclopoida and Harpacticoida) were identified to the species level, using identification keys (Einsle
1993; Janetzky et al. 1996; Meisch 2000). Insect larvae (Ephemeroptera, Plecoptera and Diptera (Chironomidae)) were the most abundant in the samples but they were omitted from detailed identification as they are representatives of the epigean spring brook (Notenboom et al. 1996).

\section{DATA ANALYSIS}

Differences in physical and chemical parameters of the spring water samples from L1 and L2 were tested with Student t-test. Since temperature, oxygen and conductivity were similar in L2 and L3, only one temporary spring (L2) was compared to the permanent one (L1). Numbers of drifted organisms were calculated to the same volume of filtered water $\left(1000 \mathrm{~m}^{3}\right)$ before statistical analysis. Sampling duration $(\mathrm{h})$, water flow velocity $\left(\mathrm{m} \mathrm{s}^{-1}\right)$, correction factor (0.8) and area of the filtering net that was in the water $\left(\mathrm{m}^{2}\right)$ were taken into account (Smock 2007). Data from the brook benthos were calculated to the surface of one square metre.

The diversity of the copepods and ostracods was expressed as Shannon diversity index $\left(\mathrm{H}^{\prime}\right)$ :

$$
\mathrm{H}^{\prime}=-\sum \frac{n i}{N} \ln \frac{n i}{N},
$$

where $n_{i}$ is number of specimens of species $i$ and $N$ is the 
total number of specimens in a sample. Shannon equitability $\left(\mathrm{H}_{\mathrm{E}}\right)$ is given by

$$
\mathrm{H}_{\mathrm{E}}=\frac{\mathrm{H}^{\prime}}{\mathrm{H}_{\max }^{\prime}},
$$

where $\mathrm{H}_{\text {max }}^{\prime}=\ln \mathrm{S}, \mathrm{S}$ being the total number of species. Indices were calculated for each drift and benthos sample using software PAST version 2.16 (Hammer et al. 2001). The results of sampling, i.e. physical and chemical parameters of the water and drift species, richness and diversity, were related to the amount of precipitation delivered on the $10^{\text {th }}, 20^{\text {th }}$ and $30^{\text {th }}$ days before sampling, using software IBM SPSS Statistics 20 (Kirkpatrick \& Feeney 2012). Species accumulation curves (Mao-Tau) were calculated separately for each zone to compare the sampling effectiveness of different habitats using software EstimateS version 8.2 (Colwell 2011). The total expected species richness was calculated for each habitat separately by the $\mathrm{ChaO}_{2}$ equation (Ugland et al. 2003; Colwell 2011). Detrended correspondence analysis (DCA) was carried out to investigate variation in drift composition and differences between springs and between benthos locations using software CANOCO 4.5 (Ter Braak \& Šmilauer 2002).

\section{RESULTS}

\section{PHYSICAL AND CHEMICAL PARAMETERS OF THE SPRING WATER}

The physical and chemical parameters of water from the springs L1 and L2 varied moderately over time and did not differ statistically between springs (Student t-test) (Tab. 1). Water temperature ranged from 6.3 to $7.1{ }^{\circ} \mathrm{C}$, $\mathrm{pH}$ from 7.5 to 8.1 , conductivity from 235 to $303 \mu \mathrm{S} \mathrm{cm}^{-1}$ (Tab. 1, Fig. 2) and oxygen concentration from 7.2 to $15.0 \mathrm{mg} \mathrm{l}^{-1}$.

Tab. 1: Physical and chemical parameters of the spring water.

\begin{tabular}{|c|c|c|c|c|c|c|c|c|}
\hline \multirow[b]{2}{*}{ Date } & \multicolumn{2}{|c|}{$\begin{array}{c}\text { Temperature } \\
\left({ }^{\circ} \mathrm{C}\right)\end{array}$} & \multicolumn{2}{|c|}{$p H$} & \multicolumn{2}{|c|}{$\begin{array}{c}\text { Conductivity } \\
\left(\mu \mathrm{S} \mathrm{cm}^{-1}\right)\end{array}$} & \multicolumn{2}{|c|}{$\begin{array}{c}\mathrm{O}_{2} \\
\left(m g l^{-1}\right)\end{array}$} \\
\hline & $\mathrm{L} 1$ & $\mathrm{~L} 2$ & L1 & L2 & $\mathrm{L} 1$ & $\mathrm{~L} 2$ & L1 & $\mathrm{L} 2$ \\
\hline Dec.10 & 6.7 & 6.6 & I & I & 270 & 272 & 8.4 & 8.5 \\
\hline Jan.11 & 6.8 & 6.7 & 7.7 & I & 266 & 266 & 7.8 & 7.5 \\
\hline Feb.11 & 7.0 & 7.0 & 8.0 & 8.0 & 291 & 298 & 8.0 & 7.9 \\
\hline Mar.11 & 6.7 & 6.7 & 7.8 & 7.7 & 279 & 283 & 12.5 & 7.2 \\
\hline May.11 & 6.5 & 6.4 & 7.9 & 8.0 & 262 & 263 & 9.0 & 9.0 \\
\hline Jun.11 & 6.4 & 6.3 & 7.8 & 7.9 & 236 & 235 & 9.3 & 9.3 \\
\hline Jul.11 & 6.8 & 6.9 & 8.1 & 8.0 & 303 & 303 & 10.4 & 11.0 \\
\hline Aug.11 & 6.7 & 6.8 & 7.8 & 8.0 & 300 & 302 & 15.0 & 13.9 \\
\hline Oct.11 & 6.9 & 7.1 & 7.7 & 7.5 & 289 & 288 & 9.6 & 11.3 \\
\hline Nov.11 & 6.6 & 6.5 & 8.1 & 7.8 & 285 & 287 & 13.5 & 13.5 \\
\hline Dec.11 & 7.0 & 6.8 & 7.9 & 7.8 & 292 & 291 & 10.2 & 10.2 \\
\hline Jan.12 & 6.9 & 6.9 & 7.8 & 7.9 & 296 & 297 & 9.8 & 9.8 \\
\hline Mean & \multicolumn{2}{|c|}{6.7} & \multicolumn{2}{|c|}{7.9} & \multicolumn{2}{|c|}{281} & \multicolumn{2}{|c|}{10.1} \\
\hline $\begin{array}{l}\text { Standard } \\
\text { deviation }\end{array}$ & \multicolumn{2}{|c|}{0.2} & \multicolumn{2}{|c|}{0.2} & \multicolumn{2}{|c|}{19} & \multicolumn{2}{|c|}{2.2} \\
\hline
\end{tabular}

On the $30^{\text {th }}$ day after precipitation only the conductivity correlated significantly with the amount of rain (Fig. 2). The Pearson correlation coefficient $(\mathrm{r}=-0.601$, $\mathrm{p}=0.039$ for L1; $\mathrm{r}=-0.593, \mathrm{p}=0.042$ for L2) showed that when the quantity of precipitation increases the value of the conductivity decreases. Conductivity did not differ between springs, with the exception of February and March 2011, when it was slightly higher in the temporary spring. The lowest conductivity values were observed in June and the highest in July and August 2011.

\section{FAUNA}

32 drift and 12 benthos samples were collected during the sampling campaign. 22 taxa were found in drift samples and 28 in benthos samples (Tab. 2). In the permanent spring L1, the stygobiont Elaphoidella phreatica (Harpacticoida) was most frequent, in contrast to the temporary springs L2 and L3 in which larvae of epigean mayflies (Ephemeroptera) and stoneflies (Plecoptera) dominated. The mouth of the spring L1 is in a solid rock, which prevented surface water and terrestrial animals from entering the drift net. In springs L2 and L3, the mouths are surrounded by scree and for that reason, more benthic and terrestrial animals were caught. In the drift samples, 12 species were found among the microcrustaceans (Tab. 2).

In the benthic samples near the spring mouth (SB1) larvae of mayflies (Ephemeroptera) and stoneflies (Plecoptera) were the most common species. In the samples from the middle section of the spring brook (SB2) Chironomidae (Diptera) dominated; in those taken near the confluence with the Radovna river (SB3) Psychrodromus fontinalis (Ostracoda) was the most abundant. Of the microcrustaceans, 20 copepod and ostracod species were found in the benthos samples.

Shannon diversity indices (Tab. 3) were highest in the permanent spring $\mathrm{L} 1$ (mean value $1.3 \pm 0.3$ ), and lower in the temporary springs L2 and L3 (mean values $0.9 \pm 0.5$ and $0.8 \pm 0.5$ ). Values of Shannon indices in all springs were higher in winter (December-January) and 


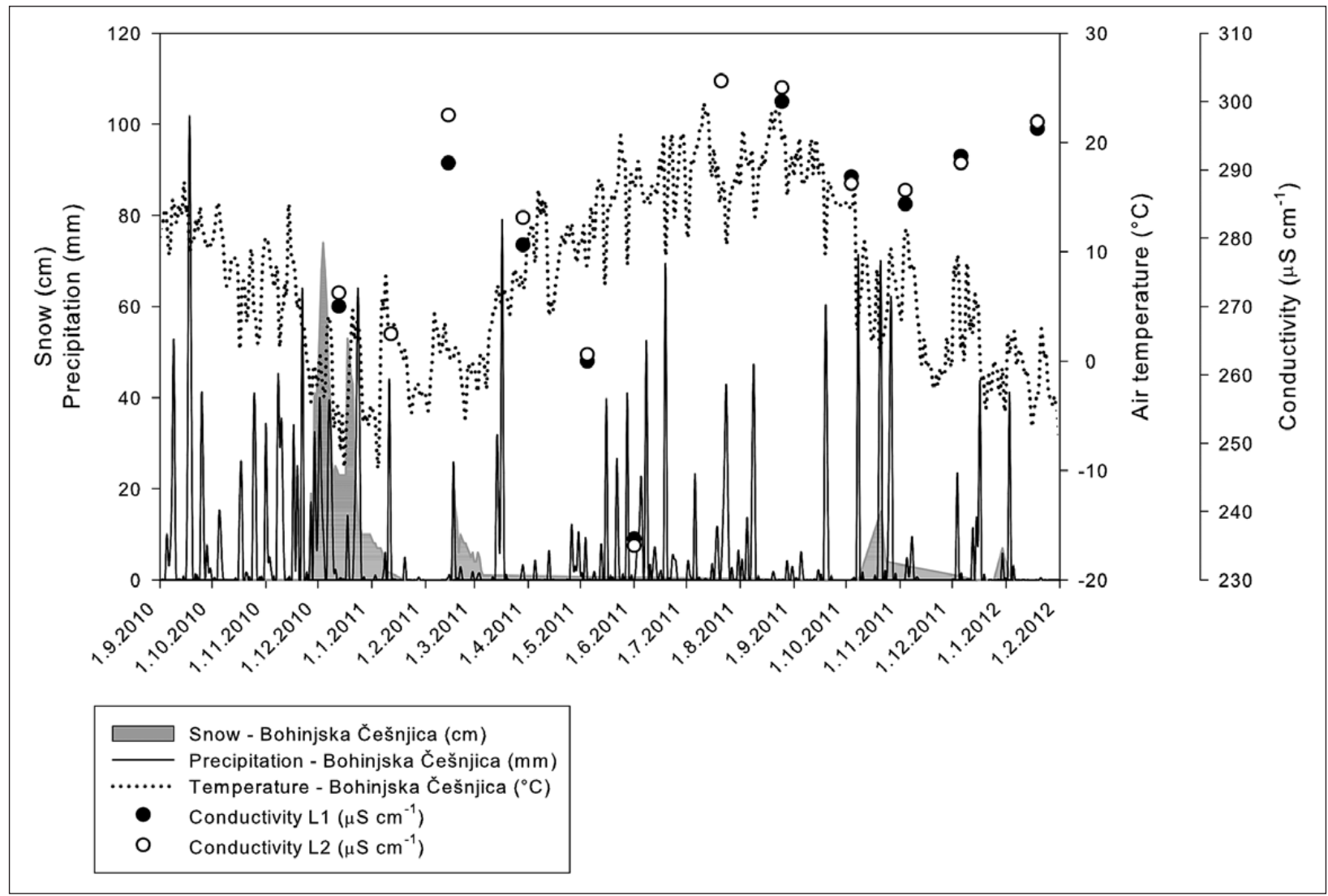

Fig. 2: Air temperature $\left({ }^{\circ} \mathrm{C}\right)$, daily precipitation $(\mathrm{mm})$ and snow $(\mathrm{cm})$ in relation to spring water conductivity $\left(\mu \mathrm{S} \mathrm{cm}^{-1}\right)$ at $L 1$ and $L 2$ from September 2010 to January 2012.

summer (June-July) than in spring and autumn (March and October). Shannon equitabilities (Tab. 3) were approximately the same for all springs (mean $0.7 \pm 0.2$ for $\mathrm{L} 1,0.7 \pm 0.3$ for $\mathrm{L} 2,0.6 \pm 0.4$ for $\mathrm{L} 3$ ), with maximum values in winter and summer, and minimum values in spring and autumn. Drift densities (Tab. 3) were highest in spring L1, with a maximum value in November 2011. In springs L2 and L3, drift densities were highest in Feb-

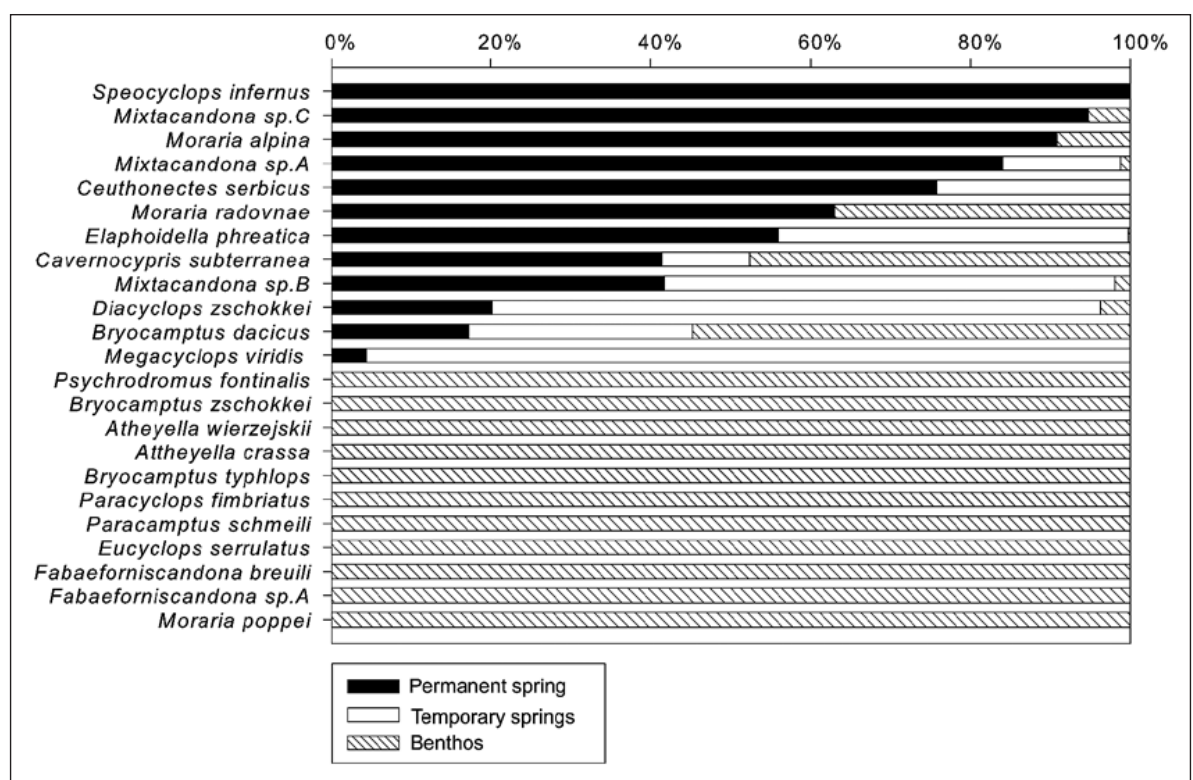

Fig. 3: Frequency of occurrence of copepods and ostracods in drift and benthos. 


\begin{tabular}{|c|c|c|c|c|c|c|}
\hline & $L 1$ & $L 2$ & $L 3$ & SB1 & $S B 2$ & SB3 \\
\hline \multicolumn{7}{|l|}{ Cyclopoida } \\
\hline Diacyclops zschokkei (Graeter, 1910) & 4.7 & 2.0 & 3.8 & 4.1 & & 0.1 \\
\hline Eucyclops serrulatus (Fischer, 1851) & & & & & & 0.6 \\
\hline Megacyclops viridis (Jurine, 1820) & 0.1 & 0.2 & 0.1 & & & \\
\hline Paracyclops fimbriatus (Fischer, 1853) & & & & 0.3 & 0.3 & 2.2 \\
\hline Speocyclops infernus (Kiefer, 1930) & 0.1 & & & & & \\
\hline \multicolumn{7}{|l|}{ Harpacticoida } \\
\hline Attheyella crassa (Sars, 1863) & & & & & 0.3 & 5.7 \\
\hline Atheyella wierzejskii (Mrazek, 1893) & & & & 0.8 & 12.6 & 4.6 \\
\hline Bryocamptus dacicus (Chappuis, 1923) & 5.1 & 0.6 & 2.8 & 14.0 & 5.7 & 16.6 \\
\hline Bryocamptus typhlops (Mrazek, 1893) & & & & 7.7 & 9.8 & 0.1 \\
\hline Bryocamptus zschokkei (Schmeil, 1893) & & & & 2.0 & 3.6 & 15.8 \\
\hline Ceuthonectes serbicus Chappuis, 1924 & 0.4 & 0.1 & 0.1 & & & \\
\hline Elaphoidella phreatica (Sars, 1862) & 47.9 & 3.6 & 10.4 & 1.2 & 0.3 & \\
\hline Moraria alpina Stoch, 1998 & 0.6 & & & 0.3 & & \\
\hline Moraria poppei (Mrazek, 1893) & & & & 0.1 & & \\
\hline Moraria radovnae Brancelj, 1988 & 3.1 & & & 0.3 & 1.3 & 2.1 \\
\hline Paracamptus schmeili (Mrazek, 1893) & & & & & 0.8 & 0.7 \\
\hline \multicolumn{7}{|l|}{ Ostracoda } \\
\hline Cavernocypris subterranea (Wolf, 1920) & 2.1 & 0.1 & & 3.5 & 3.5 & 1.4 \\
\hline Fabaeformiscandona breuili (Paris, 1920) & & & & 0.3 & & \\
\hline Fabaeforniscandona sp. A & & & & & 0.3 & \\
\hline Psychrodromus fontinalis (Wolf, 1920) & & & & & 5.4 & 29.5 \\
\hline Mixtacandona sp. A & 3.5 & 0.1 & 0.3 & 0.3 & & \\
\hline Mixtacandona sp. B & 6.5 & 0.9 & 2.3 & 0.7 & 0.9 & \\
\hline Mixtacandona sp. C & 0.2 & & & 0.1 & & \\
\hline Oligochaeta & 0.6 & 0.2 & 0.1 & 3.7 & 0.5 & 7.4 \\
\hline Nematoda & 0.4 & 0.3 & 2.4 & 3.3 & & 0.1 \\
\hline Niphargus sp. & 0.2 & 0.4 & 0.1 & & & \\
\hline Gammarus sp. & 12.6 & 0.2 & & 0.7 & 4.3 & 1.8 \\
\hline Bathynella sp. & 0.1 & & & & & \\
\hline Isopoda & 0.6 & 0.1 & 0.3 & 0.2 & & \\
\hline Mollusca & 1.4 & 1.0 & 1.8 & 2.6 & 2.9 & 0.8 \\
\hline Ephemeroptera and Plecoptera & 8.0 & 79.6 & 70.1 & 42.1 & 14.2 & 3.5 \\
\hline Chironomidae (Diptera) & 0.5 & 10.2 & 4.5 & 10.5 & 25.7 & 6.6 \\
\hline Acarina & 1.5 & 0.6 & 0.9 & 1.2 & 7.6 & 0.3 \\
\hline
\end{tabular}

Tab. 2: List of taxa from Lipnik springs' drift (L1, L2, L3) collected from December 2010 to January 2012, and, from Lipnik brook benthos (SB 1, SB 2, SB 3), collected in April 2012. The numbers indicate the proportion, in percentage, of each taxon in the total sum. ruary 2011. The number of species (Tab. 3) was highest in spring at L1 (max. 11 species in May 2011), followed by L2 (max. 6 species in December 2010 and February 2011) and L3 (max. 6 species in June 2011).

On the $20^{\text {th }}$ day after precipitations, Shannon indices and equitability indices correlated significantly with the amount of rain only in spring L2 (Tab. 4). The Pearson correlation coefficient showed a negative correlation between precipitation and diversity. The values on DCA axis 1 that best describe the change of the community composition with time (cumulative variability $33.5 \%$ ) also correlated with the amount of rain on the $10^{\text {th }}$ day after the precipitation in spring $\mathrm{L} 2$, and on the $30^{\text {th }}$ day after the precipitation in spring L3 (Tab. 4). This positive correlation between quantity of precipitation and values on the DCA axis 1 indicate the way community composition increases with precipitation. Drift densities and numbers of species did not correlate with precipitation in any of the springs (Tab. 4).

The compositions of copepod and ostracod species in drift clearly differed from those in benthos (Fig. 3). Speocyclops infernus, Ceuthonectes serbicus and Megacyclops viridis were found only in drift, while Psychrodromus fontinalis, Bryocamptus zschokkei, Atheyella wierzejskii, Attheyella crassa, Bryocamptus typhlops, Paracyclops fimbriatus, Paracamptus schmeili, Eucyclops serrulatus, Fabaeformiscandona breuili, Fabaeformiscandona sp. A and Moraria poppei were only found in benthos. Bryocamptus dacicus and Cavernocypris subterranea were present in all habitats in similar proportions. Diacyclops 


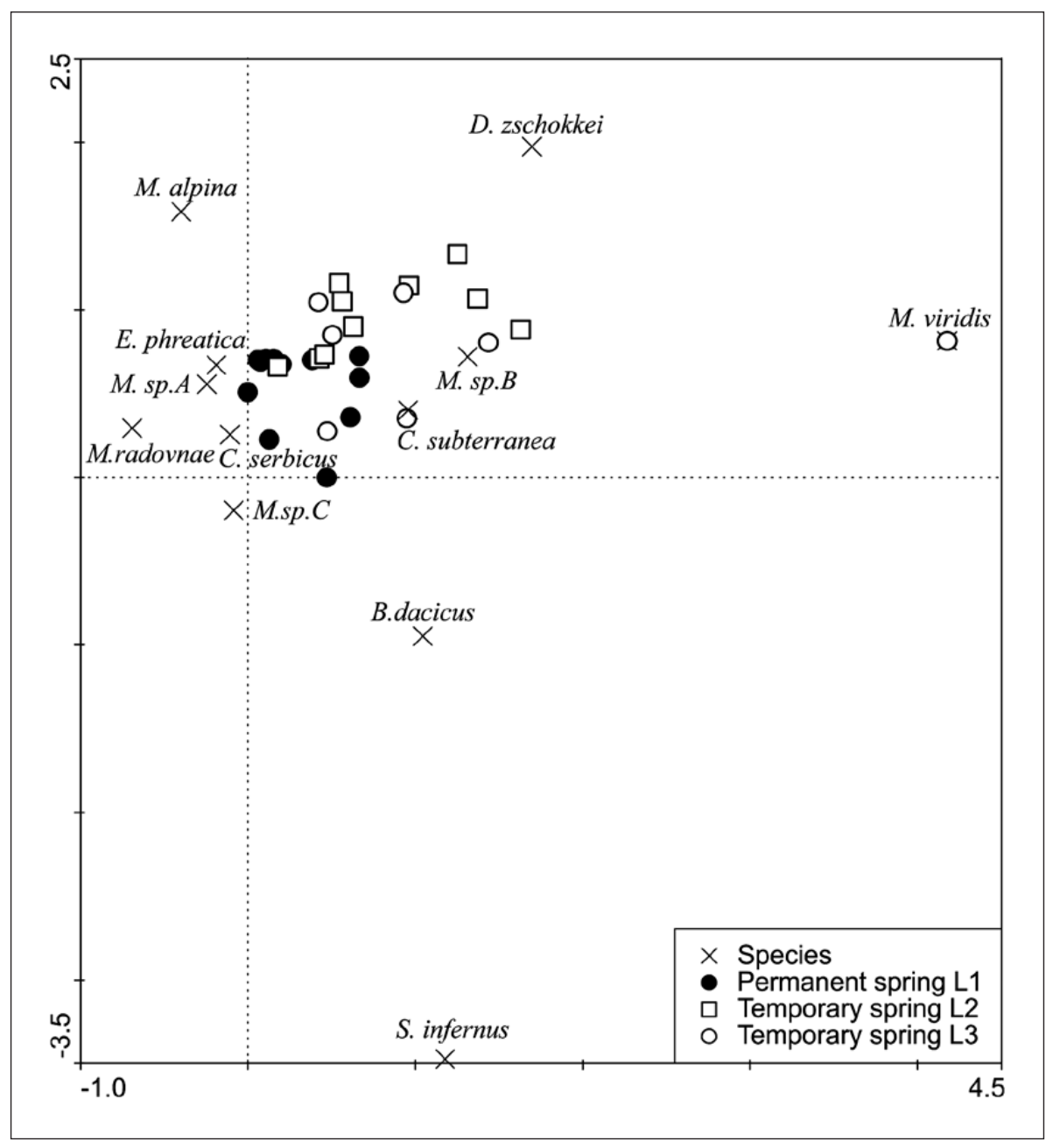

\begin{tabular}{l|c|c|c|c|c|c|c|c|c|c|c|c}
\hline & \multicolumn{3}{|c}{$H$} & \multicolumn{3}{c|}{$H_{E}$} & \multicolumn{3}{c|}{ Drift density $^{a}$} & \multicolumn{3}{c}{ No. of species } \\
\hline Date & L1 & L2 & L3 & L1 & L2 & L3 & L1 & L2 & L3 & L1 & L2 & L3 \\
\hline Dec.10 & 1.3 & 1.6 & 0.9 & 1.0 & 0.9 & 0.8 & 33 & 264 & 12 & 4 & 6 & 3 \\
\hline Jan.11 & 1.7 & 0.0 & 0.7 & 0.8 & 0.0 & 1.0 & 409 & 0 & 12 & 8 & 0 & 2 \\
\hline Feb.11 & 1.0 & 1.1 & 1.2 & 0.5 & 0.6 & 0.7 & 1542 & 395 & 852 & 10 & 6 & 5 \\
\hline Mar.11 & 0.9 & 0.0 & 0.0 & 0.8 & 0.0 & 0.0 & 38 & 0 & 0 & 3 & 0 & 0 \\
\hline May.11 & 1.2 & 1.0 & 0.0 & 0.5 & 0.9 & 0.0 & 1096 & 33 & 2 & 11 & 3 & 1 \\
\hline Jun.11 & 1.6 & 1.0 & 1.3 & 1.0 & 0.9 & 0.7 & 13 & 172 & 99 & 5 & 3 & 6 \\
\hline Jul.11 & 1.5 & 1.3 & 1.1 & 0.7 & 0.8 & 0.7 & 532 & 94 & 428 & 9 & 5 & 5 \\
\hline Aug.11 & 1.2 & 0.9 & $/$ & 0.5 & 0.9 & $/$ & 1368 & 324 & $/$ & 10 & 3 & $/$ \\
\hline Oct.11 & 0.9 & 0.7 & 0.8 & 0.4 & 0.7 & 0.8 & 1677 & 253 & 24 & 8 & 3 & 3 \\
\hline Nov.11 & 1.4 & 0.9 & $/$ & 0.6 & 0.8 & $/$ & 1831 & 43 & $/$ & 10 & 3 & $/$ \\
\hline Dec.11 & 1.3 & 1.1 & $/$ & 0.6 & 0.7 & $/$ & 499 & 46 & $/$ & 8 & 5 & $/$ \\
\hline Jan.12 & 1.6 & 1.2 & $/$ & 0.7 & 0.8 & $/$ & 856 & 108 & $/$ & 9 & 5 & $/$ \\
\hline Mean & 1.3 & 0.9 & 0.8 & 0.7 & 0.7 & 0.6 & 825 & 144 & 179 & 8 & 4 & 3 \\
\hline Standard deviation & 0.3 & 0.5 & 0.5 & 0.2 & 0.3 & 0.4 & 667 & 135 & 308 & 3 & 2 & 2 \\
\hline
\end{tabular}

${ }^{a}$ no. of specimens $1000 \mathrm{~m}^{-3}$
Fig. 4: DCA ordination diagram of drift samples based on microcrustacean fauna in $1000 \mathrm{~m}^{3}$ of water. The eigenvalue for axis 1 is $17.9 \%$ and, for axis 2, $10.7 \%$; the length gradient for axis 1 is 4.177 and, for axis 2, 1.334.
Tab. 3: Shannon diversity in$\operatorname{dex}(H)$ and equitability index $\left(H_{E}\right)$, drift densities and number of species in samples during the sampling period (December 2010 to January 2012). Data for the spring $L 3$ are absent because the spring was dry. 


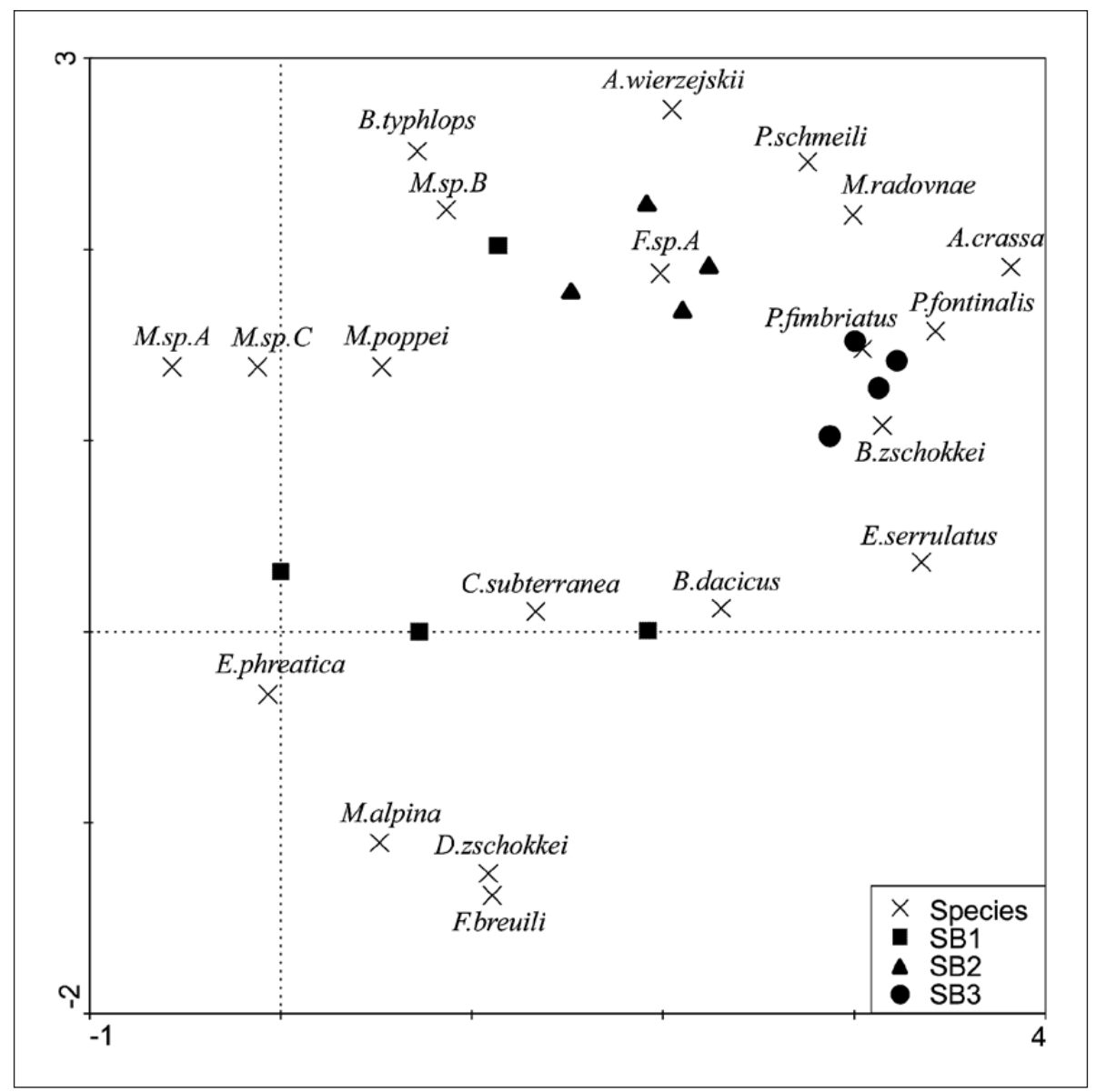

Fig. 5: DCA ordination diagram of benthic samples (number of animals $\mathrm{m}^{-2}$ ). The eigenvalue for axis 1 is $52.6 \%$ and for axis 2, $19.5 \%$; the length gradient for axis 1 is 3.224 and, for axis 2, 2.231 .

zschokkei, Mixtacandona sp. B, Mixtacandona sp. A and Elaphoidella phreatica dominated in drift and, in smaller proportions, also in benthos. Moraria radovnae, Moraria alpina and Mixtacandona sp. C were found only in drift from the permanent spring $\mathrm{L} 1$ and in benthos from the spring mouth (SB1). No species was found exclusively in drift from the temporary springs.

The DCA diagram for drift samples (Fig. 4) shows that samples from permanent and temporary springs varied most in terms of occurrence of the species Moraria alpina, Moraria radovnae, Mixtacandona sp. C and Speocyclops infernus in the permanent spring and of Megacyclops viridis and Diacyclops zschokkei in the temporary springs. The community composition differs clearly between springs L1, L2 and L3 and between the permanent and temporary springs.

The DCA diagram of benthos samples (Fig. 5) shows that samples varied most between locations on the

\begin{tabular}{|c|c|c|c|c|c|c|c|c|c|c|}
\hline & & \multicolumn{3}{|c|}{$L 1$} & \multicolumn{3}{|c|}{$L 2$} & \multicolumn{3}{|c|}{$L 3$} \\
\hline & & $P_{10}$ & $P_{20}$ & $P_{30}$ & $P_{10}$ & $P_{20}$ & $P_{30}$ & $P_{10}$ & $P_{20}$ & $P_{30}$ \\
\hline \multirow{2}{*}{$\mathrm{H}$} & $r$ & .035 & .454 & -.004 & .473 & $-.595^{*}$ & -.075 & .203 & -.041 & -.521 \\
\hline & $p$ & .915 & .138 & .990 & .121 & .041 & .816 & .629 & .923 & .185 \\
\hline \multirow{2}{*}{$\mathrm{H}_{\mathrm{E}}$} & $r$ & .505 & .360 & -.075 & .279 & $-.643^{*}$ & .140 & .318 & .416 & -.625 \\
\hline & $p$ & .094 & .251 & .817 & .380 & .024 & .665 & .442 & .306 & .098 \\
\hline \multirow{2}{*}{ Drift density } & $r$ & -.297 & -.300 & -.084 & .271 & -.333 & -.312 & -.227 & -.219 & -.285 \\
\hline & $\mathrm{p}$ & .349 & .343 & .794 & .394 & .291 & .324 & .589 & .602 & .493 \\
\hline \multirow{2}{*}{ No. of species } & $r$ & -.459 & -.128 & .175 & .380 & -.547 & -.231 & .057 & -.218 & -.307 \\
\hline & $p$ & .134 & .693 & .586 & .223 & .066 & .469 & .894 & .605 & .460 \\
\hline \multirow{2}{*}{ DCA axis 1} & $r$ & .465 & .526 & -.055 & $.665^{*}$ & -.192 & .300 & -.198 & .055 & $.938^{* *}$ \\
\hline & $p$ & .127 & .079 & .865 & .036 & .595 & .399 & .670 & .907 & .002 \\
\hline
\end{tabular}

${ }^{*}$ Correlation is significant at the 0.05 level (2-tailed) and ${ }^{*}$ at the 0.01 level (2-tailed).
Tab. 4: Correlations of Shannon diversity index $(H)$, equitability $\left(H_{E}\right)$, drift density (no. of specimens $1000 \mathrm{~m}^{-3}$ ), number of species in the samples and DCA axis 1 with precipitation. (Sampling took place on the $10^{\text {th }}\left(P_{10}\right), 20^{\text {th }}$ $\left(P_{20}\right)$ and $30^{\text {th }}\left(P_{30}\right)$ days after the precipitation). 

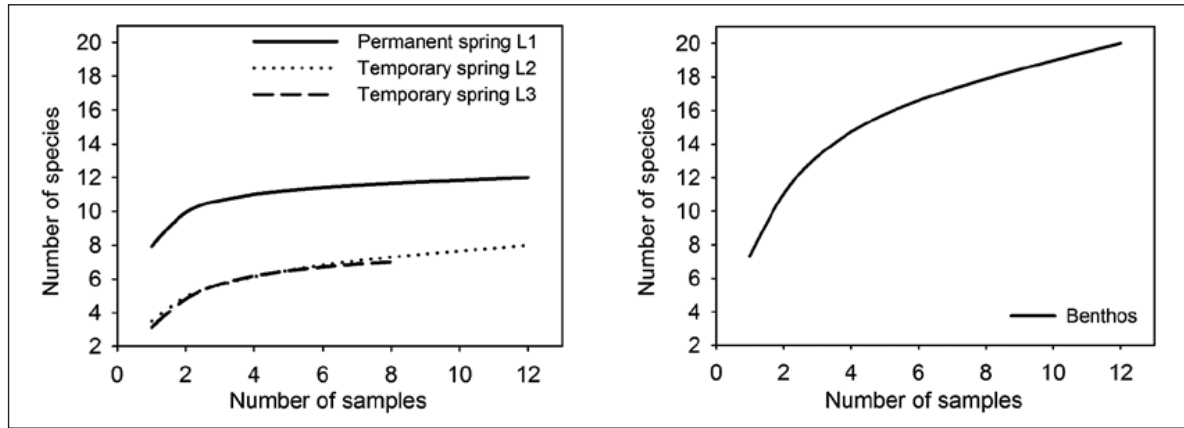

Fig. 6: Species accumulation curves combined for copepods and ostracods in all drift samples taken over a one year period (left) and in all benthic samples from three brook sites (right).

basis of occurrence of Mixtacandona sp. C, Mixtacandona sp. A, Moraria poppei, Fabaeformiscandona breuili, Moraria alpina and Elaphoidella phreatica at location SB1, Mixtacandona sp. B, Fabaeformiscandona sp. A, Bryocamptus typhlops and Atheyella wierzejskii at location SB2 and Eucyclops serrulatus and Attheyella crassa at location SB3. Samples from different locations are clearly grouped into three zones, although replicates from SB1 are not as similar to one another as in other groups.

The species accumulation curves (Fig. 6, left) for copepods and ostracods in the drift have high slopes at the beginning and then reach their asymptotes. $90 \%$ of all species were collected from 3 samplings in the permanent spring and from 7 samplings in the temporary springs. The slope of the accumulation curve for benthos (Fig. 6, right) did not reach the asymptote. The number of species, estimated using the $\mathrm{ChaO}_{2}$ equation, was 12 for permanent springs, 8 for temporary springs and 27 for benthos. In the case of drift, all species were found after 8 samplings, while in benthos we should have found 7 species more.

\section{DISCUSSION}

\section{COMPOSITION AND DIVERSITY OF DRIFTS}

In the Lipnik springs the fauna drifting from the aquifer was relatively rich. In the permanent spring all 12 copepod and ostracod species were found, in contrast to the temporary springs, where fewer species were found. Further, on 6 sampling occasions in 2009 and 2010, Mori and Brancelj (2013) found 20 copepod and ostracod species in drift from the Lipnik springs. Despite the fact that the frequency of sampling and the number of samples was higher in the present study, the number of copepod and ostracod species was lower than in Mori and Brancelj (2013).

Elaphoidella phreatica were present in all springs in the greatest abundance, followed by Diacyclops zschokkei, Bryocamptus dacicus and Mixtacandona sp. B. Elaphoidella phreatica is a typical representative of karst phreatic zones (Mori \& Brancelj 2008; Galassi et al. 2013) and its high abundance in the permanent spring suggests that the spring water is supplied from the phreatic zone. Diacyclops zschokkei inhabits preferentially the karst vadose zone, yet it can also live in the hyporheic and surface waters (Pesce 1994; Galassi et al. 2013). Bryocamptus dacicus, and probably Mixtacandona sp. $B$, are groundwater species with a prefer- ence for living in springs (Janetzky et al. 1996; Meisch 2000). Most of the copepod and ostracod species found in the drift samples were stygobionts (e.g. S. infernus, $B$. dacicus, C. serbicus, E. phreatica) but some were stygophiles (e.g. D. zschokkei) and stygoxenes (e.g. M. viridis) (Sket \& Brancelj 1992; Pesce 1994; Janetzky et al. 1996; Brancelj 2001). Moraria radovnae found in the permanent spring is an alpine stygophile and a Slovene endemic species (Brancelj 2001).

Shannon indices were higher for the drift in the permanent spring than in the temporary ones and only small differences were seen between Shannon equitabilities in the different springs. The indices indicate that, in the permanent spring, individuals in the community were more evenly distributed than in temporary springs, most probably as a result of more stable hydrological conditions. Mori and Brancelj (2006) showed that permanent springs with medium flow rates have higher diversities than others, as was shown for the drift in this study. The high biodiversity of drift samples found here is comparable to that observed in samples from Dinaric karst aquifers (Pipan \& Brancelj 2004) and indicates further development of the karst channel system, by which more living space is available due to the larger volume and the diversification of the channels. In contrast with the Karavanke moun- 
tain chain, in which no such karst system has developed (Brenčič \& Polntig 2008) and where the groundwater fauna is poor (Mori et al. 2011a), biodiversity in the well fractured limestone massif of the Julian Alps is high. Mori and Brancelj (2013) suggest that the higher species richness in the permanent spring is due to water supplied from the phreatic zone, in contrast to the lower densities and species numbers in temporary springs in which water is supplied from the vadose zone. The environment in the latter is harsh for the animals, since they are constantly rinsed by water and unable to develop populations as dense as those in more stable, saturated zones (Galassi et al. 2009). Compared with the study in which 16 karst springs of the Slovenian Alps were investigated and in which Shannon indices of macroinvertebrate communities ranged from 0.15 to 3.55 (Mori \& Brancelj 2006), Shannon indices in the Lipnik springs were lower. In Slovenia, a large number of groundwater species, especially crustacean, could be explained by a high degree of speciation due to spatial isolation, ecological partition in the case of co-occurrence, favourable and constant temperatures (also during glacial periods) and a diverse geological history (Sket 1999a, b).

\section{THE INFLUENCE OF PRECIPITATION ON DRIFTS AND SPRING WATER PARAMETERS}

Fauna drifting from the spring mouths varied over time and between springs, but no significant correlation was found between the precipitation and the drift densities or numbers of species. However, a relationship was observed between Shannon indices and equitabilities and precipitation, as well as a correlation between community composition and precipitation. For the temporary spring L2, a significant correlation with the amount of rain (sampled on the $20^{\text {th }}$ day after the precipitation) was shown for the Shannon diversity index and equitability. Changes in the community composition with time correlated with the precipitation only in temporary springs and not in the permanent one. Their correlation with the amount of rain in L2 occurred when sampling was performed on the $10^{\text {th }}$ day after the precipitation and in L3 when sampling was conducted on the $30^{\text {th }}$ day after the precipitation. In contrast, diversities in permanent spring L1 and in temporary spring L3 showed no correlation with the previous precipitation. One of the most important variables that influence surface drift is the velocity of discharge or water flow (Brittain \& Eikeland 1988). Similarly, Notenboom (1996) and Mori and Brancelj (2013), who compared springs outflow with the density of organisms, found that the highest numbers of organisms were in a weak outflow and not in intensive discharge.

In the springs, conductivity was the only water parameter that correlated with the previous precipitation (sampling on the $30^{\text {th }}$ day after the precipitation). The conductivity is defined mainly by the lithological characteristics of the substrate and its solubility. At high altitudes conductivity is lower, because the residence time of the water in the aquifer is shorter and there is not enough time for interaction between the substrate and water (Cantonati et al. 2006). Since conductivity depends on the ion concentration, increased quantity of precipitation and snow melting in the spring led to decrease in the conductivity. On the other hand, conductivity was high at lower quantities of precipitation, as a result of the longer residence time of the water in cracks and voids (Liu \& Brancelj 2014). The conductivity values of the water in the Lipnik springs were still relatively high because of the carbonate catchment area (Kanduč et al. 2012).

\section{COMPARISON OF DRIFT AND SPRING BROOK BENTHOS}

More species of copepods and ostracods were found in the spring brook benthos than in drift since, in addition to subterranean species, surface species were also present. Eleven species were found in the brook benthos alone and none exclusively in drift from temporary springs. A typical representative of the epikarst, Speocyclops infernus (Galassi et al. 2009; Papi \& Pipan 2011; Culver et al. 2012), was only found once in the permanent spring, where it could have been washed out from the epikarst. Megacyclops viridis, a stygoxen species (Janetzky et al. 1996), and Ceuthonectes serbicus, a stygobiont species (Janetzky et al. 1996), were found in all springs in small abundances and never in the brook benthos. Moraria alpina and Mixtacandona sp. $C$ were found only in drift from the permanent spring, with low occurrence in the benthos at the mouth of the spring, where they were probably transported from the spring. Moraria radovnae was found in the permanent spring and in the spring benthos, but not in the temporary springs, suggesting that it prefers more stable hydrological conditions. Bryocamptus dacicus was found in all habitats, indicating its good adaptation to the subsurface and also to surface environments.

\section{SAMPLING EFFORT AND THE ESTIMATION OF SPECIES RICHNESS}

The numbers of species in drift in springs were the same as those predicted by $\mathrm{Chao}_{2}$ equation. In a previous study (Mori \& Brancelj 2013) the numbers of species estimated with the $\mathrm{ChaO}_{2}$ equation were higher than those found in this study. Although the species accumulation curves showed that multiple samplings are needed for better assessments of species richness, in the present case more sampling did not lead to more species. The results indicate that not just the number of samples but also the sampling occasion has an important effect on the number of collected species. 
Sampling methodology has a significant impact on the assessment of species richness of subterranean fauna (Hancock \& Boulton 2009). At Lipnik spring in 2009 and 2010 drift sampling and kick sampling methods were used and it was shown that the composition of the obtained fauna differed, depending on the sampling method (Mori \& Brancelj 2013). Drift sampling cannot pro- vide an accurate density estimation of fauna living in the karst, because not all animals are washed out (e.g. larger animals can resist the pull of the current) and not all animals are from underground (e.g. surface animals caught in the filtering net) (Gibert 1986). On the other hand it is one of the few methods with which karst groundwater can be sampled.

\section{CONCLUSIONS}

It has been demonstrated that permanent and temporary Lipnik springs have similar drifting communities of copepods and ostracods although, in the permanent spring, the number of species and their abundance was higher due to more stable hydrological conditions. The difference between the three springs was shown by the correlation of diversity and community composition and with the precipitation, where only temporary springs were correlative. Communities of copepods and ostracods in spring brook benthos have been shown to differ from those in springs. In the case of karst aquifers with complex and hydrologically unpredictable environments the time of sampling appears to be more important than the frequency of sampling. Drift sampling was an effective and simple method of sampling the groundwater fauna that was able to reveal some of the hydrogeological characteristics of the aquifer. This method could be easily used in other aquifers, with the consistent sampling and adequate understanding of the study area.

\section{ACKNOWLEDGMENTS}

The author is grateful to mentors dr. Nataša Mori and prof. dr. Anton Brancelj for their help and guidance through this study, to Andreja Jerebic for the laboratory analyses and technical support, to Tina Leskošek, dr. Ire- na Bertoncelj, Basak Oz and dr. Allen Wei Liu for help in the field. The study was supported by the Slovenian Research Agency (P1-0255; Z1-2213).

\section{REFERENCES}

Boulton, A. J., Fenwick, G. D., Hancock, P. J. \& M. S. Harvey, 2008: Biodiversity, functional roles and ecosystem services of groundwater invertebrates.Invertebrate Systematics, 22, 2, 103-116. http:// dx.doi.org/10.1071/IS07024

Brancelj, A., 2001: Male of Moraria radovnae Brancelj, 1988 (Copepoda: Crustacea), and notes on endemic and rare copepod species from Slovenia and neighbouring countries.- Hydrobiologia, 453, 1, 513-524. http://dx.doi.org/10.1023/A:1013139428099

Brancelj, A., 2002: Microdistribution and high diversity of Copepoda (Crustacea) in a small cave in central Slovenia.- Hydrobiologia, 477, 1-3, 59-72. http:// dx.doi.org/10.1023/A:1021043014879
Brancelj, A., 2004: Biological sampling methods for epikarst water.- In: Jones, W. K. et al. (eds.) Epikarst: proceedings of the symposium, $1^{\text {st }}-4^{\text {th }}$ October 2003, Shepherdstown, West Virginia, USA. Karst Waters Institute, Special Publication 9, 99-103, West Virginia, Charles Town.

Brenčič, M. \& W. Polntig, 2008: Podzemne vode Karavank - Skrito bogastvo.- Geološki zavod Slovenije, Joanneum Research Forschungsgesellschaft, pp. 143, Ljubljana, Graz.

Brittain, J. E. \& T. J. Eikeland, 1988: Invertebrate drift - a review.- Hydrobiologia, 166, 1, 77-93. http://dx.doi. org/10.1007/BF00017485 
Buser, S., 1987: Osnovna geološka karta SFRJ 1:100000.Beograd.

Camacho, A. I., Valdecasas, A. G., Rodriguez, J., Cuezva, S., Lario, J. \& S. Sánchez-Moral, 2006: Habitat constraints in epikarstic waters of an Iberian Peninsula cave system.- Annales de limnologie, 42, 127-140. http://dx.doi.org/10.1051/limn/2006009

Cantonati, M., Gerecke, R. \& E. Bertuzzi, 2006: Springs of the Alps-sensitive ecosystems to environmental change: from biodiversity assessments to longterm studies.- Hydrobiologia, 562, 1, 59-96. http:// dx.doi.org/10.1007/s10750-005-1806-9

Colwell, R. K., 2011: EstimateS: Statistical Estimation of Species Richness and Shared Species from Samples.[Online] Available from: http://viceroy.eeb.uconn. edu/estimates/ [Accessed 15.2.2014].

Culver, D. C., Brancelj, A. \& T. Pipan, 2012: Epikarst Communities.- In: White, W. B. \& D. C. Culver (eds.) Encyclopedia of Caves. Academic Press, pp. 288-295, Chennai. http://dx.doi.org/10.1016/B9780-12-383832-2.00039-6

Culver, D. C. \& T. Pipan, 2013: Subterranean Ecosystems.- In: Levin S. A. (ed.) Encyclopedia of Biodiversity. Academic Press, pp. 49-62, Waltham. http:// dx.doi.org/10.1016/B978-0-12-384719-5.00224-0

Einsle, U., 1993: Süsswasserfauna von Mitteleuropa: Crustacea: Copepoda: Calanoida und Cyclopoida.Süsswasserfauna von Mitteleuropa, Fischer, pp. 208, Stuttgart.

Fišer, C. \& M. Zagmajster, 2009: Cryptic species from cryptic space: the case of Niphargus fongi sp. n. (Amphipoda, Niphargidae).- Crustaceana, 82, 5, 593-614. http://dx.doi.org/10.1163/ $156854009 X 407704$

Galassi, D. M. P., Huys, R. \& J. W. Reid, 2009: Diversity, ecology and evolution of groundwater copepods. Freshwater Biology, 54, 4, 691-708. http://dx.doi. org/10.1111/j.1365-2427.2009.02185.x

Galassi, D. M. P., Stoch, F. \& A. Brancelj, 2013: Dissecting copepod diversity at different spatial scales in southern European groundwater.- Journal of Natural History, 47, 5-12, 821-840. http://dx.doi.org/10. 1080/00222933.2012.738834

Gibert, J., 1986: Ecologie d'un système karstique jurassien. Hydrologie, Dérive animale, Transits de matières, Dynamique de la population de Niphargus (crustacé amphipode).- Société de Biospéologie, pp. 395, Moulis, Saint-Girons.

Gibert, J., 2001: Basic Attributes of Groundwater Ecosystems.- In: Griebler, C. et al. (eds.) Groundwater ecology: a tool for management of water resources. European Commission, pp. 39-52, Luxembourg.
Hahn, H. J. \& A. Fuchs, 2009: Distribution patterns of groundwater communities across aquifer types in south-western Germany.- Freshwater Biology, 54, 4, 848-860. http://dx.doi.org/10.1111/j.1365-2427 $.2008 .02132 . \mathrm{x}$

Hammer, Ø., Harper, D. A. T. \& P. D. Ryan, 2001: PAST: Paleontological statistics software package for education and data analysis.- Palaeontologia Electronica, $4,1,9$.

Hancock, P. J. \& A. J. Boulton, 2009: Sampling groundwater fauna: efficiency of rapid assessment methods tested in bores in eastern Australia.- Freshwater Biology, 54, 4, 902-917. http://dx.doi.org/10.1111/ j.1365-2427.2007.01878.x

Janetzky, W., Enderle, R. \& W. Noodt, 1996: Süsswasserfauna von Mitteleuropa: Crustacea: Copepoda: Gelyelloida und Harpacticoida.- Süsswasserfauna von Mitteleuropa, Fischer, pp. 288, Stuttgart.

Kanduč, T., Mori, N., Kocman, D., Stibilj, V. \& F. Grassa, 2012: Hydrogeochemistry of Alpine springs from North Slovenia: Insights from stable isotopes.Chemical Geology, 300, 40-54. http://dx.doi. org/10.1016/j.chemgeo.2012.01.012

Kirkpatrick, L. A. \& B. C. Feeney, 2012: A Simple Guide to IBM SPSS Statistics for Version 20.0.- Wadsworth, Cengage Learning, pp.128, United Kingdom.

Knez, M. \& A. Kranjc, 2009: Kras.- In: Pleničar, M. et al. (eds.) Geologija Slovenije. Geološki zavod Slovenije, pp. 563-574, Ljubljana.

Liu W. \& A. Brancelj, 2014: Hydrochemical response of cave drip water to snowmelt water, a case study from Velika Pasica cave, central Slovenia.- Acta Carsologica, 43, 1, 65-74. http://dx.doi.org/10.3986/ ac.v43i1.613

Malard, F., Mathieu, J., Reygrobellet, J.-L. \& M. Lafont, 1996: Biomotoring groundwater contamination: Application to a karst area in Southern France.Aquatic Sciences, 58, 2, 158-187. http://dx.doi. org/10.1007/BF00877113

Malard, F., Boutin, C., Camacho, A. I., Ferreira, D., Michel, G., Sket, B. \& F. Stoch, 2009: Diversity patterns of stygobiotic crustaceans across multiple spatial scales in Europe.- Freshwater Biology, 54, 4, 756-776. http://dx.doi.org/10.1111/j.1365-2427 .2009.02180.x

Meisch, C., 2000: Crustacea: Ostracoda.- Spektrum Akademischer Verlag, pp. 522, Heildelberg.

Moldovan, O.T., Pipan, T., Iepure, S., Mihevc, A. \& J. Mulec, 2007: Biodiversity and ecology of fauna in percolating water in selected Slovenian and Romanian caves.- Acta Carsologica, 36, 3, 493-501. http://dx.doi.org/10.3986/ac.v36i3.183 
Mori, N. \& A. Brancelj, 2006: Macroinvertebrate communities of karst springs of two river catchments in the Southern Limestone Alps (the Julian Alps, NW Slovenia).- Aquatic Ecology, 40, 1, 69-83. http:// dx.doi.org/10.1007/s10452-005-9018-y

Mori, N. \& A. Brancelj, 2008: Distribution and habitat preferences of species within the genus Elaphoidella Chappuis, 1929 (Crustacea: Copepoda: Harpacticoida) in Slovenia.- Zoologischer Anzeiger, 247, 2, 85-94. http://dx.doi.org/10.1016/j.jcz.2007.01.002

Mori, N. \& A. Brancelj, 2013: Differences in aquatic microcrustacean assemblages between temporary and perennial springs of an alpine karstic aquifer.- International Journal of Speleology, 42, 3, 9. http:// dx.doi.org/10.5038/1827-806X.42.3.9

Mori, N., Kanduč, T., Oz, B. \& A. Brancelj, 2011a: Identifying ecological indicators for the alpine groundwaters in the context of future climate change: the interdisciplinary approach.- Abstract Volume, 9th Swiss Geoscience Meeting, Zurich, $11^{\text {th }}-13^{\text {th }}$ November 2011, 238-239.

Mori, N., Oz, B., Kanduč, T. \& D. Kocman, 2011b: Ostracoda in South-eastern Alps (Slovenia): assemblages in ground waters, springs and adjacent spring brooks.- Joannea Geologie und Paläontologie, 11, $147-150$.

Notenboom, J., Hendrix, W. \& A.-J. Folkerts, 1996: Meiofauna assemblages discharged by springs from a phreatic aquifer system in the Netherlands.Netherland Journal of Aquatic Ecology, 30, 1, 1-13. http://dx.doi.org/10.1007/BF02092142

Papi, F. \& T. Pipan, 2011: Ecological studies of an epikarst community in Snežna jama na planini Arto - an ice cave in north central Slovenia.- Acta Carsologica, 40, 3, 505-513. http://dx.doi.org/10.3986/ ac.v40i3.62

Pesce, G. L., 1994: The genus Diacyclops Kiefer in Italy: a taxonomic, ecological and biogeographical upto-date review (Crustacea Copepoda Cyclopidae).Arthropoda Selecta, 3, 3-4, 13-19.

Pipan, T., 2003: Ecology of copepods (Crustacea: Copepoda) in percolation water of the selected karst caves.- Doctoral Dissertation (in Slovene with English abstract and summary), University of Ljubljana, Department of Biology, p. 130, Ljubljana.

Pipan, T., 2005: Epikarst - A Promising Habitat. Copepod fauna, its diversity and ecology: a case study from Slovenia (Europe).- Karst Research Institute at ZRC SAZU, ZRC Publishing, p. 101, Postojna Ljubljana.
Pipan, T. \& A. Brancelj, 2004: Distribution patterns of copepods (Crustacea: Copepoda) in percolation water of the Postojnska Jama Cave System (Slovenia).- Zoological Studies, 43, 2, 206-210.

Pipan, T. \& D. C. Culver, 2007: Copepod distribution as an indicator of epikarst system connectivity.- Hydrogeology Journal, 15, 4, 817-822. http://dx.doi. org/10.1007/s10040-006-0114-4

Pospisil, P., 1992: Sampling methods for groundwater animals of unconsolidated sediments.- In: Camacho, A. I. (ed.) The natural history of biospeleology. Museo Nacional de Ciencias Naturales, Consejo superior de investigaciones cient ficas, pp. 107-134, Madrid.

Sket, B., 1999a: High biodiversity in hypogean waters and its endangerment - the situation in Slovenia, the Dinaric karst, and Europe.- Crustaceana, 72, 8, 767-779. http://dx.doi.org/10.1163/ 156854099503951

Sket, B., 1999b: The nature of biodiversity in hypogean waters and how it is endangered.- Biodiversity and Conservation, 8, 10, 1319-1338. http://dx.doi. org/10.1023/A:1008916601121

Sket, B., Bole, J., Benović, A., Brancelj, A., Brglez, J., Čuček, M., Ćurčić, B., Jaklin, A., Karaman, G., Katavić, I., Kerovec, M., Kos, I., Legac, M., Mršić, N., Malej, A., Novak, T., Petkovski, S., Petkovski, T., Polenec, A., Potočnik, F., Pujin, V., Radujković, B., Števčić, Z., Tarman, K., Travizi, A., Velikonja, M., Velkovrh, F., Vidaković, J. \& D. Zavodnik, 1991: Bogastvo in raziskanost jugoslovanske favne: nižji nevretenčarji (Metazoa Invertebrata, ex. Insecta).Biološki vestnik, 39, 37-52.

Sket, B. \& A. Brancelj, 1992: Rdeči seznam ogroženih sladkovodnih nižjih rakov (Entomostraca: Anostraca, Cladocera, Copepoda, Ostracoda) v Sloveniji.Varstvo narave, 17, 165-172.

Slovenian Environment Agency, 2014: Arhiv meritev.[Online] Available from: http://www.arso.gov.si/ [Accessed $1^{\text {st }}$ February 2014]

Smart, C., 2004: Alpine karst.- In: Gunn, J. (ed.) Encyclopedia of Caves and Karst Science. Taylor and Francis Books, pp. 64-68, New York, London.

Smart, C. \& S. R. H. Worthington, 2004: Groundwater in karst.- In: Gunn, J. (ed.) Encyclopedia of Caves and Karst Science. Taylor and Francis Books, pp. 817-825, New York, London.

Smock, L. A., 2007: Macroinvertebrate dispersal.-In: Hauer, F. R. \& G. A. Lamberti (eds.) Methods in Stream Ecology. Elsevier Inc., pp. 465-488, Amsterdam. http://dx.doi.org/10.1016/B978-0123329080.50030-9 
Stein, H., Kellermann, C., Schmidt, S. I., Brielmann, H., Steube, C., Berkhoff, S. E., Fuchs, A., Hahn, H. J., Thulin, B. \& C. Griebler, 2010: The potential use of fauna and bacteria as ecological indicators for the assessment of groundwater quality.- Journal of Environmental Monitoring, 12, 1, 242-254. http:// dx.doi.org/10.1039/b913484k

Ter Braak, C. J. F. \& P. Šmilauer, 2002: CANOCO Reference manual and CanoDraw for Windows User's guide: Software for Canonical Community Ordination (version 4.5). Microcomputer Power, pp. 500, Ithaca, NY, USA.
Ugland, K. I., Gray, J. S. \& K. E. Ellingsen, 2003: The species-accumulation curve and estimation of species richness.- Journal of Animal Ecology, 72, 5, 888-897. http://dx.doi.org/10.1046/j.1365-2656 .2003.00748.x

Worthington, S. R. H. \& C. Smart, 2004: Groundwater in karst: Conceptual models.- In: Gunn, J. (ed.) Encyclopedia of Caves and Karst Science. Taylor and Francis Books, pp. 828-833, New York, London. 